\title{
Digestive tract morphology of the Neotropical piscivorous fish Cichla kelberi (Perciformes: Cichlidae) introduced into an oligotrophic Brazilian reservoir
}

\author{
Alejandra Filippo Gonzalez Neves dos Santos ${ }^{1}$, Luciano Neves dos Santos ${ }^{2}$ \\ \& Francisco Gerson Araújo ${ }^{3}$ \\ 1. Departamento de Zootecnia e Desenvolvimento Agrossocioambiental Sustentável, Universidade Federal Fluminense, \\ Rua Vital Brasil, 64, Faculdade de Veterinária, Niterói, Brasil; alejandrafilippo@ hotmail.com \\ 2. Departamento de Ecologia e Recursos Marinhos, Universidade Federal do Estado do Rio de Janeiro, Avenida Pasteur, \\ 458, Rio de Janeiro, Brasil; luciano.santos@unirio.br \\ 3. Departamento de Biologia, Universidade Federal Rural do Rio de Janeiro, Antiga BR 465, Km 47, Seropédica, Brasil; \\ gerson@ufrrj.br
}

\section{Received 13-IX-2010. C Corrected 06-I-2011. Accepted 03-II-2011.}

\begin{abstract}
Despite being one of the most well-known cichlid fish of importance to artisanal and sport fishing, and among the largest fishes in the Neotropics, data on digestive tract anatomy of peacock basses (Cichla spp.) are largely lacking, especially for non-native populations. In this paper, we describe for the first time the digestive tract morphology of Cichla kelberi, a voracious piscivore that was introduced in the 1950s into an oligotrophic and physically low-complex impoundment in Brazil. Peacock basses were collected between 1994 and 2002 in Lajes Reservoir, through gillnets ( 25 to $55 \mathrm{~mm}$ mesh; 20-50x2m), seines (10x2.5m; 8.0mm mesh), cast nets and angling. All the fishes were kept on ice in the field and then transferred to the laboratory, where they were identified, measured, weighed and dissected for digestive tract analyses. The Index of Relative ImportanceIRI was calculated for diet characterization while linear and non-linear regressions were performed to assess growth patterns of four morphological characters related to feeding (e.g. mouth width, mouth height, stomach length and intestine length) and the number of gill rakers during the $C$. kelberi ontogeny. Most digestive tract structures were directly related to the piscivorous diet of $C$. kelberi, indicating that peacock bass is a diurnal, bathypelagic and gape-size limited predator that feeds largely on shallow-water prey species within the littoral zone. Mouth width and height grew allometrically $(b>1)$ with the size of peacock bass, broadening the size range in which prey can be eaten, but especially for predators smaller than $\sim 400 \mathrm{~mm}$ of total length. Differently, stomach and intestine lengths increased isometrically $(b=1)$, which could constrain prey consumption for adult C. kelberi, especially those at advanced stages of gonadal maturation. The presence of longer-drawn, sharp and furcated gill rakers in $C$. kelberi may be related to increased prey retention in the resource-limited Lajes Reservoir, but further studies are necessary whether such features are randomly triggered by genetic or phenotypic anomalies, or effectively bring ecological advantages to the predator. In addition to contribute to improve the current biological knowledge on peacock basses, our results can be also useful to further comparisons on whether those morphological features related to feeding will change with transitions on prey consumption by C. kelberi and/or with the particular conditions of the invaded ecosystem. Rev. Biol. Trop. 59 (3): 1245-1255. Epub 2011 September 01.
\end{abstract}

Key words: Cichlid, peacock bass, ecomorphology, diet, invasive species, reservoir.

Peacock basses (Cichla spp.) are the major group of piscivorous cichlids in South America, which are native of the Amazon, Tocantins and Orinoco river basins, and of the smaller rivers draining the Guiana to the Atlantic Ocean (Kullander \& Ferreira 2006). All Cichla species are large ( $>500 \mathrm{~mm}$ of total lenght), visual-diurnal, and voracious predators, preying largely on small fishes, but occasionally consuming shrimp and other aquatic invertebrates when adults (Winemiller et al. 2001, Kullander \& Ferreira 2006). Although peacock basses 
collectively inhabit a diversity of habitats ranging from streams to large reservoirs, the universal requirement of all Cichla species appears to be high water transparency, warm temperatures, and access to lentic habitats for feeding and/or reproduction (Winemiller et al. 2001). Because of their great popularity as sport fishes or to control undesirable forage fishes, peacock basses are also intentionally introduced into many tropical and subtropical freshwater systems around the world (e.g. Brazil, Hawaii, Panama, Puerto Rico and Florida), sometimes to the detriment of native fish populations (Zaret \& Paine 1973, Santos et al. 2001, Latini \& Petrere Jr 2004).

Within the 15 peacock bass species currently recognized by systematists, Cichla kelberi (Kullander \& Ferreira 2006) deserves special attention since it was introduced into most Brazilian watersheds to enhance game and commercial fisheries or to control undesirable fishes (Santos et al. 2008, Espínola et al. 2009). Until this recent revision, C. kelberi was often misidentified as Cichla ocellaris or Cichla monoculus, two close congeners that are very similar in body shape and colouration. After that revision, most peacock bass introductions succeeded in Brazilian reservoirs appear to be of C. kelberi. However, since this species shares many morphometric and meristic features with $C$. monoculus, Cichla pleiozona and even $C$. ocellaris, taxonomic confusion probably remains considerable for many non-native populations (Kullander \& Ferreira 2006).

The anatomy of the digestive tract in fish is closely related to the diet and type of food consumed (Winemiller 1989, Wainwright \& Richard 1995). In addition, to help with the taxonomic differentiation of close related Neotropical species (Graça \& Pavanelli 2007), provide risk assessment of invasive species on native fish assemblages (Hill et al. 2004), or contribute to implement control measures for non-native populations (Bergmann \& Motta 2005, García-Berthou 2007), studies on feeding morphology can be also used to identify the length at which fish undergo life history thresholds and/or transitions (Kováč et al. 1999, Hellig et al. 2010). Recent studies have investigated the feeding biology of cichlids, particularly focusing on the trophic morphology of little-known species (Gordon \& Bills 1999, Cochran-Biederman \& Winemiller 2010, Hellig et al. 2010) or the predation-related impacts of non-indigenous populations (Bergmann \& Motta 2005, Fugi et al. 2008). Surprisingly, studies on the digestive tract morphology of Cichla species are still lacking, despite their recognizable value as game fishes and their increasing importance as invaders in the tropics (Espínola et al. 2009, Santos et al. 2009). In this paper, the digestive tract morphology of $C$. kelberi, a voracious piscivore that was introduced in the 1950s into Lajes Reservoir, an oligotrophic and physically low-complex impoundment in Brazil, is first described. In addition to the general hypothesis that morphological features are close related to diet and feeding habit of $C$. kelberi, we expected that our study could contribute to improve the current biological knowledge on peacock basses and also to improve the biological knowledge on non-native $C$. kelberi populations.

\section{MATERIALS AND METHODS}

Study area: Lajes Reservoir $\left(22^{\circ} 42^{\prime} \mathrm{N}\right.$

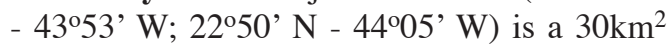
impoundment, located $415 \mathrm{~m}$ above mean sea level in Rio de Janeiro State, south-eastern Brazil. This reservoir was filled between 1905 and 1908 mainly for hydroelectric purposes, damming streams and diverting small rivers of the East Hydrographic Basin (Araújo \& Santos 2001). Lajes Reservoir is oligotrophic (i.e. $<20 \mu \mathrm{gL}^{-1}$ total $\mathrm{P} ;<400 \mu \mathrm{gL}^{-1}$ total $\mathrm{N}$ ) and largely surrounded by well-preserved stretches of Atlantic Rainforest, but it has experienced recent trends of nutrient enrichment, due to increased anthropogenic activities (i.e. diffuse pollution) and high water retention time (286 days) (Santos et al. 2004, Guarino et al. 2005). Because of vegetation removal prior to reservoir filling and wide water level fluctuations (i.e. up to $12 \mathrm{~m}$ per year) from dam 
operation routine, Lajes Reservoir is structurally homogeneous, lacking aquatic macrophytes and other natural submerged structures (Santos et al. 2008). The non-native peacock bass $C$. kelberi was introduced into the reservoir at the 1950s to control forage fish overpopulation and improve local angling (Santos et al. 2001). Despite the probable adverse impacts on the indigenous fish species, legal management actions to protecting $C$. kelberi (i.e. minimum capture size, spawning season protection and bag limits) already exists in Lajes Reservoir.

Fish collection: Peacock basses were collected monthly from January to December in 1994 and 1996, from April 1999 to March 2000 and from April 2001 to March 2002, through gillnets ( 25 to $55 \mathrm{~mm}$ mesh; 20-50x2m), seines $(10 \times 2.5 \mathrm{~m} ; 8.0 \mathrm{~mm}$ mesh), cast nets and angling. All fishes were kept on ice in the field and then transferred to the laboratory, where they were identified (Kullander \& Ferreira 2006), measured (total length - $\mathrm{L}_{\mathrm{T}}$ to nearest $0.1 \mathrm{~mm}$ ), weighed (to the nearest $10^{-3} \mathrm{~g}$ ) and dissected for digestive tract analyses. Voucher specimens were preserved in $10 \%$ formalin and later deposited in the Ichthyological Collection at Laboratory of Fish Ecology, Federal Rural University of Rio de Janeiro, UFRRJ, Brazil.

Morphological measurements: The following morphological variables of C. kelbe$r i$, presumed to be related to feeding (Keast \& Webb 1966, Piet 1998), were recorded: (1) total length $\left(\mathrm{L}_{\mathrm{T}}\right)$; (2) mouth width $\left(\mathrm{W}_{\mathrm{M}}\right)$ - maximum width of the gape with the mouth fully opened; (3) mouth height $\left(\mathrm{H}_{\mathrm{M}}\right)$ - maximum height of the gape with the mouth fully opened; (4) stomach length $\left(\mathrm{L}_{\mathrm{S}}\right)$ - distance between anterior and posterior part of the stomach; (5) intestine length $\left(\mathrm{L}_{\mathrm{I}}\right)$, distance between pylorus and anus, fully extended without stretching. The total length and intestine length were measured at $1 \mathrm{~mm}$ precision, and the other variables to the nearest $0.01 \mathrm{~mm}$. Teeth were characterized according to Lagler et al. (1977), and the shape and number $\left(\mathrm{G}_{\mathrm{N}}\right)$ of gill rakers were recorded (CochranBiederman \& Winemiller 2010), with furcated rakers having a common base being counted as a single raker. The intestinal quotient $\left(\mathrm{I}_{\mathrm{Q}}\right)$ was calculated according to Bertin (1958), by dividing the intestine length $\left(\mathrm{L}_{\mathrm{I}}\right)$ per the total length of the predator $\left(\mathrm{L}_{\mathrm{T}}\right)$.

Diet characterization: Food items were examined using a stereoscopic microscope and identified, counted, weighed (to the nearest $10^{-5} \mathrm{~g}$ ) and measured (to the nearest $10^{-2} \mathrm{~mm}$ ). The Index of Relative Importance-IRI (Pinkas et al. 1971) was calculated for diet characterization with percents by number $(\% \mathrm{~N})$, by weight $(\% \mathrm{~W})$ and frequency of occurrence $(\% \mathrm{O})$, where: IRI=\%Ox $(\% \mathrm{~N}+\% \mathrm{~W})$. The percent IRI (\%IRI) was calculated dividing the IRI values from each food item by the sum of all IRI values and multiplying the result by 100 . Fishes with empty stomachs were excluded from dietary analysis.

Data analysis: Linear regressions were performed to assess growth patterns of the morphological characters during the ontogeny of C. kelberi. The measurements of the four morphological attributes $\left(\mathrm{W}_{\mathrm{M}}, \mathrm{H}_{\mathrm{M}}, \mathrm{L}_{\mathrm{S}}\right.$ and $\left.\mathrm{L}_{\mathrm{I}}\right)$ and the number of gill rakers $\left(\mathrm{G}_{\mathrm{N}}\right)$ were regressed against the $C$. kelberi total length $\left(\mathrm{L}_{\mathrm{T}}\right)$. All regressions were carried on $\log _{10}$-transformed data (both dependent and independent variables) in order to normalize the residuals and to stabilise the variances (Levene's test, $\mathrm{p}>0.05$ ). In addition to reaching the assumptions for applying parametric tests, the $\log _{10}$ transformation also allowed the identification of the allometric relationships directly. The significance of the slope (b) obtained in each regression was tested (Student t-test) in order to determine if the morphological attributes showed isometric $(b=1.0)$ or allometric growth $(b \neq 1.0)$ in relation to the C. kelberi length (Sokal \& Rohlf 1995).

Generalized Additive Models (GAMs) were also fitted to raw (untransformed) data, whenever the null hypothesis of isometric relationship was rejected, to appraise whether the growth patterns of morphological characters would change during the ontogeny of $C$. kelberi. Generalized additive models are an 
extension of generalized linear models that do not assume a particular functional relationship between the response variable and the predictor (Lepš \& Šmilauer 2003). The model complexity of GAMs was chosen by the stepwise selection procedure using the Akaike information criterion (AIC), as available in CANOCO 4.5. AIC considers not only the goodness of fit but also parsimony, penalizing very complex models (Burnham \& Anderson 1998).

\section{RESULTS}

\section{Feeding morphology}

Mouth: Cichla kelberi has a protrusible and prognathous mouth, with the lower jaw being more prominent than the upper jaw. Mouth is wide, approaching to a full circle in shape, with width ranging from $7.9 \%$ to $17.7 \%$ (average of $13.7 \pm 0.12 \mathrm{SE}$.) and height from $7.2 \%$ to $17.4 \%$ (average of $13.2 \pm 0.12 \mathrm{SE}$ ) of C. kelberi $\mathrm{L}_{\mathrm{T}}(\mathrm{n}=154)$. Despite being slightly greater than 1.0 (Table 1), the slopes (b) of $\mathrm{W}_{\mathrm{M}}$ and $\mathrm{H}_{M}$ regressions differed significantly from that value $\left(\mathrm{W}_{\mathrm{M}}: \mathrm{t}=2.66, \mathrm{p}<0.01 ; \mathrm{W}_{\mathrm{M}}: \mathrm{t}=1.98\right.$, $\mathrm{p}<0.05$ ), indicating a positive allometry for both structures with $C$. kelberi growth. $\mathrm{W}_{\mathrm{M}}$ and $\mathrm{H}_{M}$ variables were well fitted to a linear function (Fig. 1A, B), resulting in highly significant values for $\mathrm{R}^{2}$ (Table 2 ).

Teeth: Cichla kelberi bear numerous, short and pointed jaw teeth (cardiform), in both ascending and descending processes of the premaxilla. The pharyngobranchial apparatus is formed by two large pharyngeal plates resembling a $Y$ at the lower orobranchial and by two opposing, comparatively small and elliptic plates at the upper orobranchial.

Gill rakers: Gill rakers are found only on the first pair of branchial arches. Gill rakers are long (1-4mm for superior branch; 3-15mm for inferior branch), broad, pointed, and also widely spaced $(0.2-3.4 \mathrm{~mm}$ for upper branch and 0.4-4.1 for lower branch) $(n=99)$. There is a range of 15-24 gill rakers for the sum of upper and lower branches, with 3-8 gill rakers for the upper branch and 11-16 for the lower branch. The $\mathrm{G}_{\mathrm{N}}$ did not change during $C$. kelberi ontogeny $\left(b=0.04, p>0.05, R^{2}=0.01\right.$; Table 1). There are furcated gill rakers (bi or trifurcated), resembling small hooks, that were recorded as subdivisions of the main raker in some individuals (Fig. 2). From a total of 99 examined individuals, 7 had furcated rakers, with 4 occurring on upper branches of branchial arch (2 bifurcated and 2 trifurcated) and 3 on lower branches (all trifurcated). Aberrant rakers were recorded in peacock basses ranging from 245 to $485 \mathrm{~mm} \mathrm{~L}_{\mathrm{T}}$.

Stomach and intestine: The stomach is a well-developed and elastic structure, ranging from 22 to $137 \mathrm{~mm}$ in length for the examined population ( $\mathrm{n}=179$, Table 1$)$, which corresponded to $9.4-46.0 \%$ (average of $23.1 \pm 0.46 \mathrm{SE}$ ) of C. kelberi $\mathrm{L}_{\mathrm{T}}$. It has a gastric mucous membrane with several longitudinal inner pleats,

TABLE 1

Relationships of feeding traits with total length $\left(L_{T}\right)$ of $C$. kelberi

$\begin{array}{cccccccc}\text { Dependent variable } & \mathrm{N} & \text { Mean } & \text { Range } & \text { SE } & \mathrm{y}=\log _{10} \mathrm{a}+\mathrm{blog}_{10} \mathrm{x} & \text { S.E. (b) } & \mathrm{R}^{2} \\ \mathrm{~W}_{\mathrm{M}} & 154 & 41.7 & 17.0-72.0 & 1.06 & \mathrm{~W}_{\mathrm{M}}=-1.00+1.0 \mathrm{LTT}^{\mathrm{L}} & 0.03 & 0.93 \\ \mathrm{H}_{\mathrm{M}} & 155 & 39.9 & 14.0-70.0 & 0.99 & \mathrm{H}_{\mathrm{M}}=-0.99+1.05 \mathrm{~L}_{\mathrm{T}} & 0.03 & 0.91 \\ \mathrm{~L}_{\mathrm{S}} & 179 & 67.4 & 22.0-137.0 & 1.72 & \mathrm{~L}_{\mathrm{S}}=-0.50+0.94 \mathrm{~L}_{\mathrm{T}} & 0.06 & 0.60 \\ \mathrm{~L}_{\mathrm{I}} & 219 & 213.4 & 78.0-430.0 & 4.90 & \mathrm{~L}_{\mathrm{I}}=-0.03+0.95 \mathrm{~L}_{\mathrm{T}} & 0.05 & 0.60 \\ \mathrm{G}_{\mathrm{N}} & 99 & 18.7 & 15-22 & 0.13 & \mathrm{G}_{\mathrm{N}}=1.18+0.04 \mathrm{~L}_{\mathrm{T}} & 0.03 & 0.01\end{array}$

Mean, standard errors (SE) and range are expressed in mm for dependent variables, except for $\mathrm{G}_{\mathrm{N}}$ that are expressed in numbers. The size of $C$. kelberi ranged from 133.4-550mm $\mathrm{L}_{\mathrm{T}}$ for all morphometric relationships. Except for $\mathrm{G}_{\mathrm{N}}$, all slopes (b) and determination coefficients $\left(\mathrm{R}^{2}\right)$ were significant $(\mathrm{p}<0.01) . \mathrm{N}=$ number of examined $C$. kelberi; $\mathrm{W}_{\mathrm{M}}=$ mouth width; $\mathrm{H}_{\mathrm{M}}=$ mouth height; $\mathrm{L}_{\mathrm{S}}=$ stomach length; $\mathrm{L}_{\mathrm{I}}=$ intestine length; $\mathrm{G}_{\mathrm{N}}=$ number of gill rakers. 


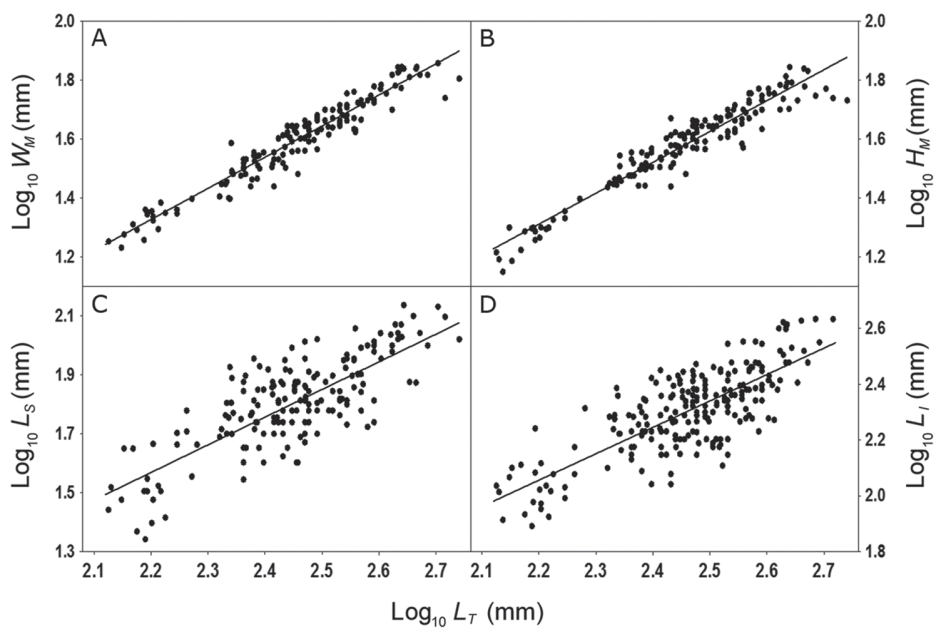

Fig. 1. Scatter plots and linear regressions for $\log _{10}$-transformed data of the morphometric variables $\left(\mathrm{W}_{\mathrm{M}}, \mathrm{H}_{\mathrm{M}}, \mathrm{L}_{\mathrm{S}}\right.$ and $\left.\mathrm{L}_{\mathrm{I}}\right)$ as a function of the total length of $C$. kelberi $\left(\mathrm{L}_{\mathrm{T}}\right) . \mathrm{W}_{\mathrm{M}}=$ mouth width $(\mathrm{A}) ; \mathrm{H}_{\mathrm{M}}=$ mouth height $(\mathrm{B}) ; \mathrm{L}_{\mathrm{S}}=$ stomach length $(\mathrm{C})$; $\mathrm{L}_{\mathrm{I}}=$ intestine length (D). The $\mathrm{G}_{\mathrm{N}}$ was omitted because this variable did not shift during C. kelberi ontogeny and $\mathrm{R}^{2}$ obtained from linear regression was not significant (see Table 1).

TABLE 2

Diet of C. kelberi collected in Lajes Reservoir, basing on the analysis of 254 stomachs

\begin{tabular}{|c|c|c|c|c|c|}
\hline Food category & Prey items & $\% \mathrm{O}$ & $\% \mathrm{~N}$ & $\% \mathrm{~W}$ & $\%$ IRI \\
\hline \multicolumn{6}{|l|}{ Fishes } \\
\hline & C. kelberi & 43.18 & 30.34 & 26.73 & 54.22 \\
\hline & T. rendalli & 20.45 & 6.21 & 51.18 & 25.82 \\
\hline & Astyanax spp. & 13.64 & 6.21 & 15.35 & 6.47 \\
\hline & O. hepsetus & 4.54 & 1.38 & 2.23 & 0.36 \\
\hline & P. eigenmanni & 4.54 & 1.38 & 1.31 & 0.27 \\
\hline & R. parahybae & 2.27 & 1.38 & 2.40 & 0.19 \\
\hline & C. lacustris & 2.27 & 0.69 & 0.96 & 0.08 \\
\hline \multicolumn{6}{|l|}{ Insects } \\
\hline & Odonata & 11.36 & 48.96 & 0.21 & 12.29 \\
\hline & Hemiptera & 2.27 & 0.69 & 0.04 & 0.04 \\
\hline Fish eggs & & 4.54 & 1.38 & 0.38 & 0.17 \\
\hline \multicolumn{6}{|l|}{ Crustaceans } \\
\hline & Macrobrachium sp. & 2.27 & 0.69 & 0.47 & 0.06 \\
\hline Plants & & 2.27 & 0.69 & 0.01 & 0.03 \\
\hline
\end{tabular}

$\% \mathrm{O}=$ percent occurrence of prey items, \% N=percent by number of prey items, \% W=percent by weight of prey items, \% IRI=percent index of relative importance. 


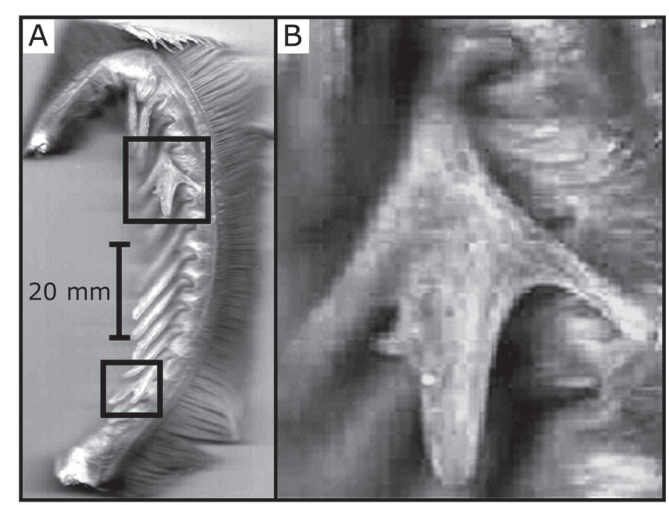

Fig. 2. First pair of branchial arches of C. kelberi, with biand trifurcated gill rakers (A). The trifurcated gill raker is also showed in greater detail (B).

but lacking pyloric caeca. The intestine is a short and tubular structure $(n=219)$, which ranged from 78 to $430 \mathrm{~mm}$ in length (Table 1), corresponding to an $\mathrm{I}_{\mathrm{Q}}$ of 0.38-1.12 (average of $0.71 \pm 1.05 \mathrm{SE}$ ). The slope (b) did not significantly departure from 1.0 for $\mathrm{L}_{\mathrm{S}}(\mathrm{t}=1.28$, $\mathrm{p}>0.05)$ and $\mathrm{L}_{\mathrm{I}}(\mathrm{t}=1.26, \mathrm{p}>0.05)$, indicating these structures increased isometrically with $C$. kelberi $\mathrm{L}_{\mathrm{T}}$. Except for $\mathrm{G}_{\mathrm{N}}$, all linear relationships were significant, however, the values of the determination coefficient $\left(\mathrm{R}^{2}\right)$ for $\mathrm{L}_{\mathrm{S}}$ and $\mathrm{L}_{\mathrm{I}}$ (Table 2) were comparatively lower than those found for $\mathrm{W}_{\mathrm{M}}$ and $\mathrm{H}_{\mathrm{M}}$, as a result of a greater data scattering around the linear response for the former variables (Fig. 1C, D).

Allometric relationships: The response curves (GAMs) revealed that the relationships of $\mathrm{W}_{\mathrm{M}}$ and $\mathrm{H}_{\mathrm{M}}$ with $C$. kelberi $\mathrm{L}_{\mathrm{T}}$ are best explained by a quadratic curve (Fig. 3). A nonlinear trend was found for $\mathrm{W}_{\mathrm{M}}$ (AIC; non-linear $\left.\mathrm{F}_{1,153}=8.49, \mathrm{p}=0.004\right)$ and $\mathrm{H}_{\mathrm{M}}$ (AIC, non-linear $\left.\mathrm{F}_{1,154}=23.92, \mathrm{p}<0.001\right)$, indicating that mouth proportions changed gradually with $C$. kelberi growth (e.g. gradual allometry). The response curves also revealed that both $\mathrm{W}_{\mathrm{M}}$ and $\mathrm{H}_{\mathrm{M}}$ grow isometrically or even more rapidly than $\mathrm{L}_{\mathrm{T}}$ for C. kelberi smaller than $350-400 \mathrm{~mm}$, but not for larger individuals (Fig. 3).

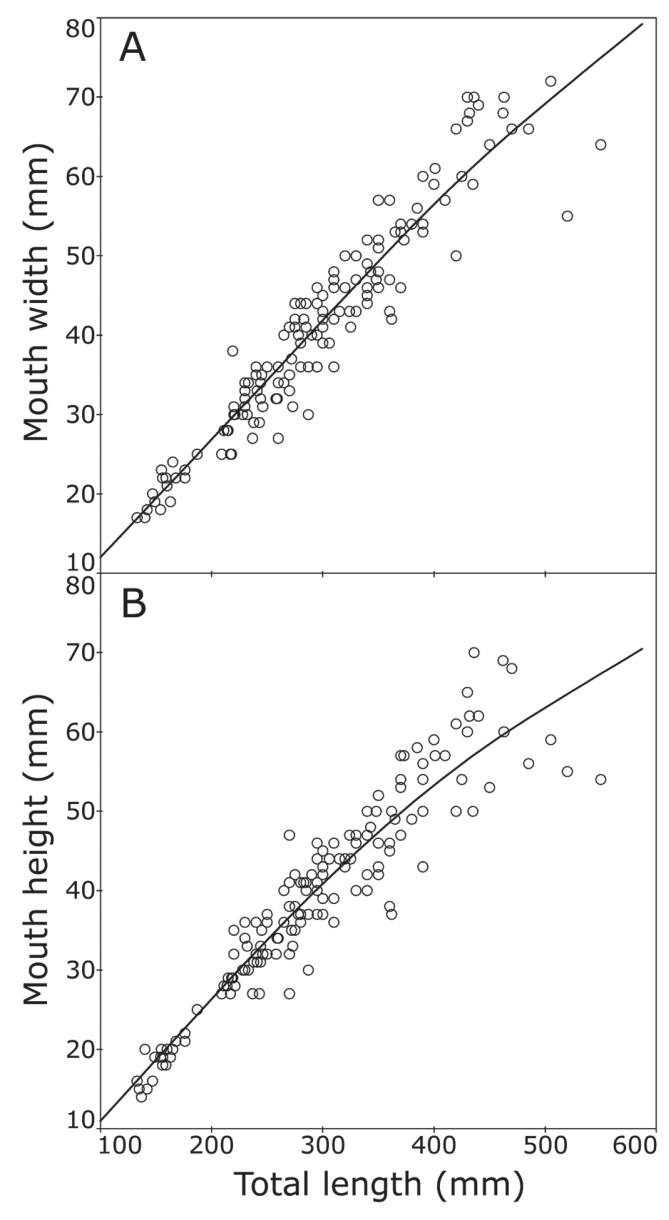

Fig. 3. Relationship of mouth width (A) and mouth height (B) with total length of $C$. kelberi. Lines are the generalized additive models selected by the Akaike information criterion.

\section{Diet}

Of 254 stomachs examined, 119 (46.9\%) had food contents, but only 44 (17.3\%) contained identified and quantified items, with recognizable fishes being recorded in 35 stomachs (13.8\%). This high occurrence of empty stomachs was probably related to a high gastric digestion together with low food consumption rate exhibited by $C$. kelberi in response to the warm and oligotrophic conditions of Lajes Reservoir. The diet consisted of 12 food items sorted into 5 categories: fishes, insects, fish eggs, crustaceans and plants (Table 2). Small 
fishes accounted for $87.4 \%$ IRI of overall diet, ranking in the following decreasing order: $C$. kelberi, Tilapia rendalli (Boulenger 1897), Astyanax spp., Oligosarcus hepsetus (Cuvier 1829), Pimelodella eigenmanni (Boulenger 1891), Rhamdia quelen (Quoy \& Gaimard 1824) and Crenicichla lacustris (Castelnau 1855). Data on the two species of Astyanax recorded for Lajes Reservoir (Araújo \& Santos 2001) - Astyanax cf. bimaculatus L. and Astyanax parahybae Eigenmann, 1908 - were pooled together because species recognition was often impossible.

Cichlids were the major prey within the fish category ( $80.1 \%$ IRI), and juveniles of $C$. kelberi were the major prey fish (54.2\%IRI), indicating intense cannibalism. $T$. rendalli was the second most important item, while $C$. lacustris made a small contribution. Characids accounted for 6.8\%IRI, with Astyanax spp. being the most important item of this group, whereas Heptapterids, especially P. eigenmanni, contributed with only $0.5 \%$ for IIR. The remained categories amounted to $12.6 \%$ IRI, mainly nymphs and adults of Odonata (Insects). Gut analysis revealed only entire fishes in the $C$. kelberi stomachs and that all prey had been reoriented after they were caught, to allow the predator to swallow the head first and lying on their side.

\section{DISCUSSION}

Cichla kelberi was predominantly piscivorous in Lajes Reservoir, agreeing well with the features of the digestive tract structures. The orientation of the mouth is indicative of the location of the prey relative to the predator (Gatz 1979) or to the relative depth in the water-column at which feeding generally occurs (Winemiller 1991). The mouth of $C$. kelberi is typical of fishes that obtain food from the middle to upper layers of the water column or in shallow littoral zones (Hugueny \& Pouilly 1999, Winemiller 2001, Pouilly et al. 2003). Shallow-water littoral zone species (C. kelberi, T. rendalli, C. lacustris, Astyanax spp. and $O$. hepsetus) accounted for $87 \%$ IRI of all food items and 99\%IRI of prey fishes ingested by $C$. kelberi in Lajes Reservoir, whereas benthic-deepwater fishes ( $P$. eigenmanni and $R$. quelen) accounted for only $0.5 \%$ and $1 \%$ IRI respectively. Williams et al. (1998) reported a similar feeding habit for Cichla orinocensis Humboldt, 1821 in Guri Reservoir, which foraged mostly in shallow, structured habitats within littoral zone where Crenicichla wallacii Regan, 1905, other cichlids, and the characid Hemigrammus micropterus Meek, 1907 were the dominant preys.

The prognathous-protractile mouth of $C$. kelberi is related to a mechanism of prey capture that uses a flow of water generated by a rapid drop in buccal pressure created as the buccal cavity rapidly expands (Wainwright et al. 2001). Furthermore, the cardiform teeth (pre-maxillaries and pharyngeals) of $C$. kelberi are typical of predatory species that swallow prey whole with little evidence of mastication, the teeth functioning in prey handling and preventing prey escape (Wootton 1999). Our results indicated that $C$. kelberi is a whole-fish swallower, agreeing with previous assertions of Winemiller et al. (1997) and Jepsen et al. (1997) for three other Cichla species. According to Gill (2003), gape-size limited predators (such as $C$. kelberi) leads to a size range of prey encompassing small prey at the lower limits of visual detection or which are physically too small to be retained by gill rakers to those at the upper limits, which are too large for the jaw apparatus.

In C. kelberi, gill rakers were found only at the first pair of arches, agreeing in number and shape with the general descriptions of Kullander \& Ferreira (2006) for all species of the genus Cichla. According to Lagler et al. (1977), the gill rakers of piscivorous species are overall short, strong, sharp, and widely spaced to avoid prey escaping or gill damaging. The gill rakers of $C$. kelberi were, however, a rather longer-drawn and sharper than those found by Liparelli (1999) for Cichla cf. ocellaris (probably a misidentification of $C$. kelberi or Cichla piquiti), which could increase the effectiveness of prey retention. Given the 
virtual lack of other records in the literature, bi and trifurcated gill rakers are expected to be not a common characteristic in piscivorous fish, but they occurred in C. kelberi. Nevertheless, furcated rakers arising as small hooks from the main raker are related to increased food intake by planktivorous fishes (Lazzaro 1987). $\mathrm{Bi}$ and trifurcated rakers can not be related to food filtration in the piscivorous C. kelberi, but they might enhance the effectiveness of prey retention in the resource-limited Lajes Reservoir or even help in the protection of gill filaments. The high occurrence of empty stomachs indicates that $C$. kelberi probably experiences some sort of food deprivation in Lajes Reservoir but further research are necessary to make clear whether morphological differentiation in $C$. kelberi rakers are merely related to genetic or phenotypic anomalies by chance or effectively bring ecological advantages to the predator (e.g. improved prey retention or gill protection).

Overall the morphology of the stomach and intestine of C. kelberi (e.g. the short digestive tract, the muscular and elastic stomach, and the short intestine) matched with general descriptions for carnivorous fish. The size and distention of the stomach are constrained by the space available in the abdominal cavity of the predator (Gill 2003), which can strongly limit the size and the quantity of prey ingested (Hahn et al. 2000, Nilsson \& Brönmark 2000). Stomach size increased isometricaly in relation to $C$. kelberi's body size, allowing the ingestion of larger prey with growth. However, the stomach size could be constraining the ingestion of large prey for larger $C$. kelberi, since adult individuals (ca. $>300 \mathrm{~mm} \mathrm{~L}_{\mathrm{T}}$ ), may have space restrictions in the abdominal cavity due to the increased gonadal volume during reproductive period (Souza et al. 2008, Gomiero et al. 2009).

The length of the intestine is associated with rates of food intake, and differences in intestine size are related to alterations in the food absorption surface (Pouilly et al. 2003). Overall the intestine is shorter in carnivores than herbivore or omnivore species. The values of the intestinal quotient $\left(\mathrm{I}_{\mathrm{Q}}\right)$, between 0.38 and 1.12 for $C$. kelberi, were similar to those proposed by Bertin (1958) for carnivorous fish (0.2 to 2.5) and close to those found by Pouilly et al. (2003) for neotropical piscivores (0.93 to 1.23). Low values of $\mathrm{I}_{\mathrm{Q}}$ can occur because of the existence of traits, as pharyngeal teeth and/or strong digestive enzymes, which play important roles in digestion. Basile-Martins et al. (1986) recorded an increasingly carnivorous diet for Pimelodus maculatus Lacepède, 1803 according to its ontogenetic development, which coincided with a gradual decrease in $\mathrm{I}_{\mathrm{Q}}$ values. As the $\mathrm{L}_{\mathrm{I}}$ grew isometrically with the $\mathrm{L}_{\mathrm{T}}$ in C. kelberi, $\mathrm{I}_{\mathrm{Q}}$ values did not change through the ontogeny of the predator, indicating that $C$. kelberi experienced negligible alterations in diet composition during growth.

Our study is probably the first to combine a description of feeding patterns with regressions models fitted to morphological attributes to investigate the trophic morphology of $C$. kelberi. Hill et al. (2004) and Hoeinghaus et al. (2006) modelled the relationships of gape size (e.g. $\mathrm{W}_{M}$ or $\mathrm{H}_{\mathrm{M}}$ ) with body length for other peacock bass species, also examining their major implications on prey consumption. However, these studies did not provide any information on whether mouth proportions increased with body growth (e.g. isometrically or allometrically) or if changes in those morphometric characters were related to life history thresholds. Rather than indicating that mouth proportions changed gradually with $C$. kelberi growth, the non-linear relationships found for $\mathrm{W}_{\mathrm{M}}$ and $\mathrm{H}_{\mathrm{M}}$ in our study, argues on the need of further research to address whether such morphometric changes would be coupled with transitions on prey consumption. Nevertheless, if our findings would be further compared with those from other native or introduced populations of $C$. kelberi, they would be an interesting opportunity to test whether morphological features related to feeding will change with the particular conditions of the ecosystem (i.e. trophic status, limnological characteristics, habitat complexity and the amount and quality of preys). 


\section{ACKNOWLEDGMENTS}

We were grateful to LIGHT Services of Electricity S.A for logistic support. This work was partially funded by Brazilian Agency for Research Development (CNPq), Brazilian Ministry of Education Coordination for Personal Training (CAPES) and LIGHT Services of Electricity S.A. This study is part of the Alejandra Santos' M.Sc. dissertation (Graduate Course in Animal Biology, Federal Rural University of Rio de Janeiro).

\section{RESUMEN}

A pesar de ser uno de los peces cíclidos más conocidos por su importancia para la pesca artesanal y deportiva, y entre los más grandes peces en el Neotrópico, los datos sobre la anatomía del tracto digestivo de los pavones (Cichla spp.) están bastante deficientes, especialmente para las poblaciones no nativas. En este trabajo se describe por primera vez la morfología del tracto digestivo de Cichla kelberi, un piscívoro voraz que se introdujo en la década de 1950 en un embalse oligotrófico y físicamente de baja complejidad en Brasil. Los pavones se recogieron entre 1994 y 2002 en el embalse Lajes, con redes de enmalle (25 a 55mm de malla, 20-50x2m), redes de cerco (10x $2.5 \mathrm{~m}, 8.0 \mathrm{~mm}$ de malla), atarrayas y pesca. Todos los peces se mantuvieron en hielo en el campo y luego fueron trasladados al laboratorio, donde fueron identificados, medidos, pesados y disectados para el análisis del tracto digestivo. El Índice de Importancia Relativa, el IIR se calculó para la caracterización de la dieta, mientras que las regresiones lineales y no lineales se realizaron para evaluar los patrones de crecimiento de cuatro caracteres morfológicos relacionados con la alimentación (por ejemplo: ancho de la boca, altura de la boca, longitud del estómago y longitud del intestino) y el número de branquiespinas en la ontogenia en $C$. kelberi. La mayoría de las estructuras del tracto digestivo estaban directamente relacionadas con la dieta de los piscívoros C. kelberi, lo que indica que el pavón es un depredador diurno, batipelágico y limitado por el tamaño de la boca abierta ya que se alimenta en gran medida de presas en aguas poco profundas de la zona litoral. El ancho de la boca y la altura tuvieron un crecimiento alométrico ( $\mathrm{b}>1$ ) con el tamaño de pavones, y se amplió el rango de tamaño en el que las presas se pueden ser comidas, pero sobre todo para los depredadores menores de $\sim 400 \mathrm{~mm}$ de longitud total. A diferencia, las longitudes del estómago y el intestino aumentaron isométricamente $(b=1)$, lo que podría limitar el consumo de presas para adultos de C. kelberi, especialmente aquellos en etapas avanzadas de la maduración gonadal. La presencia de branquiespinas marcadas, agudas y furcadas en $C$. kelberi puede estar relacionada con un incremento en la retención de presas en los recursos limitados del embalse Lajes, pero son necesarios más estudios si tales características son desencadenadas al azar por anomalías genéticas o fenotípicas, o efectivamente son una ventaja ecológica para el depredador. Además de contribuir con el mejoramiento del conocimiento biológico actual en los pavones, nuestros resultados también pueden ser útiles para estudiar si las características morfológicas relacionadas con la alimentación van a cambiar con las transiciones en el consumo de presas por C. kelberi y/o con las condiciones particulares del ecosistema invadido.

Palabras clave: ciclidos, pavón, ecomorfología, dieta, especies invasivas, embalses.

\section{REFERENCES}

Araújo, F.G. \& L.N. Santos. 2001. Distribution and composition of fish assemblages in Lajes Reservoir, Rio de Janeiro, Brazil. Rev. Bras. Biol. 61: 563-576.

Basile-Martins, M.A., M.N. Cipoli \& H.M. Godinho. 1986. Alimentação do mandi, Pimelodus maculatus Lacepede, 1803, (Osteichthyes, Pimelodidae), de trechos dos rios Jaguari e Piracicaba, São Paulo - Brasil. Bol. Inst. Pesca 13: 17-29.

Bergmann, G.T. \& P.J. Motta. 2005. Diet and morphology through ontogeny of the nonindigenous Mayan cichlid 'Cichlasoma (Nandopsis)' urophthalmus (Günther 1862) in southern Florida. Environ. Biol. Fish. 75: 205-211.

Bertin, L. 1958. Traité de Zoologie. Chapter 8, Appareil digestif. Masson, Paris.

Burnham, K.P. \& D.R. Anderson. 1998. Model selection and inference. Springer-Verlag, New York, New York, USA.

Cochran-Biederman, J.L. \& K.O. Winemiller. 2010. Relationships among habitat, ecomorphology and diets of cichlids in the Bladen River, Belize. Environ. Biol. Fish. 88: 143-152.

Espínola, L.A., C.V. Minte-Vera \& H.F. Júlio-Júnior. 2009. Invasibility of reservoirs in the Paraná Basin, Brazil, to Cichla kelberi Kullander and Ferreira. Biol. Invasions 12: 1873-1888.

Fugi, R., K.D.G. Luz-Agostinho \& A.A. Agostinho. 2008. Trophic interaction between an introduced (peacock bass) and a native (dogfish) piscivorous fish in a Neotropical impounded river. Hydrobiology 607: 143-150. 
García-Berthou, E. 2007. The characteristics of invasive fishes: what has been learned so far? J. Fish. Biol. 71: $1-23$.

Gatz, A.J. 1979. Community organization in fishes as indicated by morphological features. Ecology 60 : 711-718.

Gill, A.B. 2003. The dynamics of prey choice in fish: the importance of prey size and satiation. J. Fish. Biol. 63: $105-116$.

Gomiero, L.M., G.A. Villares Junior \& F. Naous. 2009. Reproduction of Cichla kelberi Kullander and Ferreira, 2006 introduced into an artificial lake in Southeastern Brazil. Braz. J. Biol. 69: 175-183.

Gordon, A.K. \& I.R Bills. 1999. Aspects of the feeding and reproductive biology of the Lake Tanganyikan cichlid, Lamprologus ornatipinnis (Pisces, Cichlidae). Environ. Biol. Fish. 55: 431-441.

Graça, W.J. \& C.S. Pavanelli. 2007. Peixes da planície de inundação do alto Rio Paraná e áreas adjacentes. EDUEM, Maringá, Paraná, Brazil.

Guarino, A.W.S., C.W.C. Branco, G.P. Diniz \& R. Rocha. 2005. Limnological characteristics of an old tropical reservoir (Ribeirão das Lajes Reservoir, RJ, Brazil). Acta Limnol. Bras. 17: 129-141.

Hahn, N.S., R.L. Delariva \& V.E. Loureiro. 2000. Feeding of Acestrorhynchus lacustris (Characidae): a postimpoundment studies on Itaipú Reservoir, Upper Paraná River, PR. Braz. Arch. Biol. Tecnol. 43: 207-213.

Hellig, C.J., M. Kerschbaumer, K.M. Sefc \& S. Koblmüller. 2010. Allometric shape change of the lower pharyngeal jaw correlates with a dietary shift to piscivory in a cichlid fish. Naturwissenschaften 97 663-672.

Hill, J.E., L.G. Nico, C.E. Cichra \& C.R. Gilbert. 2004 Prey vulnerability to peacock cichlids and largemouth bass based on predator gape and prey body depth. Proc. Annu. Conf. Southeast Assoc. Fish. and Wildl. Agencies 58: 47-56.

Hoeinghaus, D.J., K.O. Winemiller, C.A. Layman, D.A. Arrington \& D.B. Jepsen. 2006. Effects of seasonality and migratory prey on body condition of Cichla species in a tropical floodplain river. Ecol. Fresh. Fish. 15: 398-407.

Hugueny, B. \& M. Pouilly. 1999. Morphological correlates of diet in an assemblage of West African freshwater fishes. J. Fish. Biol. 54: 1310-1325.
Jepsen, D.B., K.O. Winemiller \& D.C. Taphorn. 1997. Temporal patterns of resource partitioning among Cichla species in a Venezuelan blackwater river. J. Fish. Biol. 51: 1085-1108.

Keast, A. \& D. Webb. 1966. Mouth and body form relative to feeding ecology in the fish fauna of a small lake, Lake Opinicon, Ontario. J. Fish. Res. Board. Can. 23: 1845-1874.

Kováč, V., G.H. Copp \& M.P. Francis. 1999. Morphometry of the stone loach, Barbatula barbatula: do mensural characters reflect the species' life history thresholds? Environ. Biol. Fish. 56: 105-115.

Kullander, S.O. \& E.J.G. Ferreira. 2006. A review of the South American cichlid genus Cichla, with descriptions of nine new species (Teleostei: Cichlidae) Ichthyol. Expl. Fresh. 17: 289-398.

Lagler, K.F., J.E. Bardach, R.R. Miller \& D.R.M. Passino. 1977. Ichthyology. Wiley \& Sons, New York, New York, USA.

Latini, A.O. \& M. Petrere Jr. 2004. Reduction of a native fish fauna by alien species: an example from Brazilian freshwater tropical lakes. Fish. Man. Ecol. 11: 71-79.

Lazzaro, X. 1987. A review of planktivorous fishes: their evolution, feeding, behaviours, selectivities and impacts. Hydrobiology 146: 97-167.

Lepš, J. \& P. Šmilauer. 2003. Multivariate analysis of ecological data using CANOCO. Cambridge, Cambridge, United Kingdom.

Liparelli, T. 1999. História natural do tucunaré Cichla cf. ocellaris (Teleostei, Cichlidae) no Rio Piquirí, Pantanal de Paiaguás, Estado do Mato Grosso do Sul. Dissertation, Universidade Estadual Paulista, São Paulo, Brazil.

Nilsson, P.A. \& C. Brönmark. 2000. Prey vulnerability to a gape-size limited predator: behavioural and morphological impacts on northern pike piscivory. Oikos 88: 539-546.

Piet, G.J. 1998. Ecomorphology of a size-structured tropical freshwater fish community. Environ. Biol. Fish. 51: $67-86$.

Pinkas, L., M.S. Oliphant, I.L.K. Iverson. 1971. Food habits of albacore, bluefin tuna, and bonito in California waters. Calif. Dept. Fish. Game Fish. Bull. 152: 1-105.

Pouilly, M., F. Lino, J.G. Bretenoux \& C. Rosales. 2003. Dietary morphological relationships in a fish 
assemblage of the Bolivian Amazonian floodplain. J. Fish. Biol. 62: 1137-1158.

Santos, A.F.G.N., L.N. Santos, F.G. Araújo. 2004. Water level influences on body condition of Geophagus brasiliensis (Perciformes, Cichlidae) in a Brazilian oligotrophic reservoir. Neot. Ichthyol. 2: 151-156.

Santos, A.F.G.N., L.N. Santos, E. García-Berthou \& C. Hayashi. 2009. Could native predators help to control invasive fishes? Microcosm experiments with the Neotropical characid Brycon orbignyanus. Ecol. Fresh. Fish. 18: 491-499.

Santos, L.N., A.F. Gonzalez \& F.G. Araújo. 2001. Dieta do tucunaré-amarelo Cichla monoculus (Bloch \& Schneider) (Osteichthyes, Cichlidae), no Reservatório de Lajes, Rio de Janeiro, Brasil. Rev. Bras. Zool. 18: 191-204.

Santos, L.N., F.G. Araújo \& D.S. Brotto. 2008. Artificial structures as tools for fish habitat rehabilitation in a Neotropical reservoir. Aquat. Cons. 18: 896-908.

Sokal, R.R. \& F.J. Rohlf. 1995. Biometry. W.H. Freeman \& Company, New York, USA.

Souza, J.E., E.N. Fragoso-Moura, N. Fenerich-Verani, O. Rocha \& Jr. Verani. 2008. Population structure and reproductive biology of Cichla kelberi (Perciformes, Cichlidae) in Lobo Reservoir, Brazil. Neot. Ichthyol. 6: 201-210.
Wainwright, P.C. \& B.A. Richard. 1995. Predicting patterns of prey use from morphology with fishes. Environ. Biol. Fish. 44: 97-113.

Wainwright, P.C., L.A. Ferry-Graham, T.B. Waltzek, A.M. Carroll, C.D. Hulsey \& Grubich Jr. 2001. Evaluating the use of ram and suction during prey capture by cichlid fishes. J. Exp. Biol. 204: 3039-3051.

Williams, J.D., K.O. Winemiller, D.C. Taphorn \& L. Balbas. 1998. Ecology and status of piscivores in Guri, an oligotrophic tropical reservoir. North Am. J. Fish. Man. 18: 274-285.

Winemiller, K.O. 1989. Ontogenetic diet shifts and resource partitioning among piscivorous fishes in the Venezuelan llanos. Environ. Biol. Fish. 26: 177-199.

Winemiller, K.O. 1991. Ecomorphological diversification in lowland freshwater fish assemblages from five biotic regions. Ecol. Monog. 61: 343-365.

Winemiller, K.O. 2001. Ecology of peacock cichlids (Cichla spp.) in Venezuela. J. Aquar. Aquat. Sci. 9: 93-112.

Winemiller, K.O., D.C. Taphorn, A.B. Duque. 1997. Ecology of Cichla (Cichlidae) in two blackwater rivers of South Venezuela. Copeia 4: 690-696.

Wootton, R.J. 1999. Ecology of teleost fishes. Kluwer Academic, Amsterdam, The Netherlands.

Zaret, T.M. \& R.T. Paine. 1973. Species introduction in a tropical lake. Science 182: 449-455. 